The paradigms configuration is unconditional. N.A. Kiasashvili translation has the following paradigmatic organization of the text: motivated with the text, logically heterogeneous, hyperactual, monofunctional, conceptual paradigms that are united on mental level. The paradigms configuration is unconditional. The main differences between the paradigmatic organization of analyzed texts and textual depth are caused by different language structure (English is an analytical language and Russia is a synthetic one). Functioning of determiners is one of English language feature. There is no such morphological category in Russian. Presence or absence of determiners influence the process of text perception greatly.

Discussion: Comparative analysis of original texts and their translations may not just improve the methodology of translation equivalence estimation, but determine the key languages features that influence the act of a text perception.

Keywords: paradigmatic analysis, functional linguistics, postmodern.

Vitae

Maria Orobinska is $\mathrm{PhD}$ major in philology, Associate professor of Philology and Linguodidactics Department at Kharkiv National Automibile and Highway University. Her scientific interests include text linguistics, functional linguistics, psychological linguistic, languages comparative analysis.

Correspondence: mariaorobinska@gmail.com

Lubov Bezkorovaina is $\mathrm{PhD}$ major in pedagogy, Head of Department of Philology and Linguodidactics at Kharkiv National Automibile and Highway University. Her scientific interests include methodology of teaching second languages, usage of modern technologies in teaching second languages.

Correspondence: rki314@ukr.net

DOI 10.31558/1815-3070.2018.36.11

УДК 811.161.2’282

Олена Поліщук

\title{
МІФОПОЕТИЧНИЙ СВІТ ЛЕСІ УКРАЇНКИ: ЛІНГВОПЕРСОНОЛОГІЙНИЙ АСПЕКТ
}

У статті йдеться про проблему мовної особистості Лесі Українки та ї̈ виявлення через поетику міфу. Визначене поняття «мовна особистість», схарактеризовані ї̈ специфічні риси. Досліджено феномен міфотворчості в художньо-драматургічному тексті. Проаналізовані засоби вербалізації міфу у творчості Лесі Украӥнки (на матеріалі драматичного твору «Лісова пісня»).

Ключові слова: концепт, лінгвокультурема, міфологема, міфопоетика, мовна особистість, лінгвоперсонологія, лінгвоперсона, ідіостиль.

Постановка проблеми у загальному вигляді та їі зв'язок із важливими науковими завданнями. Сучасну лінгвістику характеризує певна антропоцентричність, зацікавлення окремою мовною особистістю чи лінгвоперсоною. Початок цього етапу в розвитку лінгвістики, на думку більшості мовознавців, належить Ю. Караулову, який уводить у широкий науковий обіг термін «мовна особистість» 3 відповідними диференційними ознаками. Саме він першим доводить можливість і продуктивність дослідження персонажа художнього тексту як моделі мовної особистості. На вивченні мовної особистості в ії цілісності концентрує увагу такий розділ мовознавчої науки, як лінгвоперсонологія. Сучасна лінгвістика, розвиваючись в антропологічному напрямі, вивчає індивідуально-авторські мовні картини світу, закодовану інформацію, своєрідність засобів і способів вербалізації концептосфери окремого митця, ментально-культурні зв'язки мови 3 мисленням, внутрішнім світом, загальнолюдськими та національними цінностями індивіда. Отже, актуальність дослідження зумовлена тим, що воно проведено в руслі сучасної антропоцентричної парадигми лінгвістики, одним із завдань якої є вивчення мови конкретного письменника з позицій теорії лінгвоперсонології.

Аналіз останніх досліджень та публікацій. Українське мовознавство має значні успіхи у вивченні художніх дискурсів як особливих мовно-естетичних витворів, ментально маркованих знаків української культури. Традиції української школи лінгвостилістичного вивчення ідіолекту письменника започатковані в роботах Л. Булаховського, О. Потебні, І. Франка, обгрунтовані в працях С. Єрмоленко, В. Калашника, Г. Колесника, Л. Мацько, А. Мойсієнка, Л. Пустовіт, В. Русанівського, Н. Сологуб, Л. Ставицької, Г. Сюти, Ю. Шевельова й багатьох інших дослідників. На початку ХХ ст. питання персоналізму активно опрацьовували М. Бердяєв, Л. Шестов, а сам термін уперше було використано Ф. Шлеєрмахером (1799 р.). У лінгвістичному просторі сучасних українських студіювань помітними є дослідження з лінгвоперсонології таких науковців, як В. Білошицька («Комунікативна особистість як феномен політичної лінгвокультури», 2017), О. Гольник («Міф у художньому світі Євгена Маланюка», 2013), А. Загнітко («Теорія лінгвоперсонології», 2017). Дослідження мовної особистості Л. Українки проводилося такими авторами як В. Агеєва, О. Забужко, Н. Балабуха, Л. Зубік, М. Зушман, М. Крупка, Л. Оляндер, В. Сірук-Поліщук, М. Хмелюк, Л. Щітка. Дослідженню власне міфологічного дискурсу у творчості письменниці присвятили свої праці В. Агеєва, О. Бондарєва, Т. Мейзерська, Я. Поліщук, Л. Скупейко, С. Хороб.

(С Поліщук O., 2018 
Вирішення невирішених раніше частин загальної проблеми. У центрі пропонованої статті лінгвоперсона Лесі Українки та її виявлення через поетику міфу. Вибір письменниці як об'єкта дослідження зумовлений тим, що авторська мовна картина світу, іiі зв'язок з міфотворчістю та власне мовна особистість Лесі Українки в останні десятиріччя викликає все більше зацікавлення. 3' явилися нові дослідження, проте на даному етапі вивчення мови Л. Українки з позицій теорії лінгвоперсонології у руслі сучасної антропоцентричної парадигми лінгвістики не зазнало достатнього дослідження.

Постановка завдання. Метою дослідження є аналіз мовної особистості Лесі Українки та її виявлення через поетику міфу.

Виклад основного матеріалу дослідження й обгрунтування отриманих наукових результатів. У наш час питання міфологізації творчості є досить важливими, оскільки, на думку багатьох дослідників, в історичному плані сплеск індивідуальної та масової міфотворчості зазвичай припадає на переломні епохи, на періоди соціальних потрясінь та кардинальних змін людського світогляду. Наприклад, за словами А. А. Федорова, «у XX столітті інтерес до міфу став глобальним» (Fedorov 8), а дослідник Є. М. Мелетинський зазначає, що такий інтерес спричинив не менш глобальну реміфологізацію. ХХ ст. й справді вирізняється як століття наукових відкриттів і світових катастроф (Meletinskiy 89). Творчість Лесі Українки припадає на період «зламу» століть (зокрема iï зріла творчість - це початок XX ст.). О. Забужко - теж письменниця «зламу» (але вже інших століть - XX-XXI), який теж характеризується суттєвими змінами в суспільстві як українському, так і світовому.

Лінгвокультурологічний аналіз текстів становить особливий предмет дослідження. Людина пізнає культуру, коли засвоює їі тексти, тому тексти є справжніми сховищами культури. У дослідженнях із проблеми мова-культура мова постає як передавач культурних цінностей. Основними категоріями лінгвокультурологічного аналізу є концепт і лінгвокультурема. Також поряд із ними все більшої ваги набуває термін «міфологема».

Поняття концепту прийшло із філософії та логіки. Трактування терміну «концепт» грунтоване в основному на семантиці латинського conceptus: 1) «збирати, вбирати у себе»; 2) «уявляти»; 3) «написати, сформулювати»; 4) «формувати»; 5) «походити, з'являтись, виникати». Останні десятиліття поняття концепту переживає період актуалізації та переосмислення. Цей термін ще й досі не має єдиного визначення, хоча й міцно закріпився в сучасній лінгвістиці. В. Телія вважає, що концепт - це продукт людської думки і постає явищем ідеальним, а тому притаманним людській свідомості взагалі, а не лише тільки мовній. Концепт - це конструкт, він не відновлюється, а «реконструюється» через своє мовне вираження і позамовне знання (Вагt). Зважаючи на різноманітність тлумачень концепту, В. Карасик та Г. Слишкін чітко виокремлюють параметри відношень концепту до мови, культури і свідомості мовця; свідомість - місце перебування концепту; концепт ментальна проекція елементів культури; мова й мовлення - сфери, у яких опредметнюється концепт (Karasyk 76). А. Загнітко пропонує розуміти концепт як глобальну одиницю мисленнєвої діяльності, «квант структурованого знання». Дослідник відзначає, що люди «мислять концептами, їхня парадигматика виливається у синтагматичні вияви у мовленнєвій діяльності. Упорядкована сукупність концептів у людській свідомості утворює концептосферу свідомості» (Zahnitko “Klasyfikatsiyni typolohiyi kontseptiv” 13). Послуговуючись напрацюваннями А. Загнітка, можемо відзначити таку характеристику концептів, як універсалізм. Вираження концептів не обмежується мовою, але мова є одним із найпотужніших засобів для цього.

Іншим ключовим поняттям лінгвокультурології є лінгвокультурема. За В. Воробйовим, на відміну від слова та лексико-семантичного варіанта як власне мовних одиниць, лінгвокультурема включає в себе сегменти не тільки мови (мовного значення), а й культури (позамовне культурне значення), що репрезентується відповідним знаком. Лінгвокультурема як комплексна міжрівнева одиниця постає діалектичною єдністю лінгвістичного й екстралінгвального (поняттєвого і предметного) змісту. Ця одиниця більш «глибока» за своєю суттю, ніж слово (Vorob’ev 45). Н. Кирилова та А. Афанасьєва розглядають лінгвокультурему як «абстрактну сутність, конкретним вираженням якої є мовна одиниця певної структури (лексема або фразеологічна одиниця), що включає в себе не тільки денотативно-сигніфікативне значення, а й культуроносні семи, що виражають певні культурні конотації» (Afanas'eva, Kyryllova 73). О. Хроленко до лінгвокультурем відносить слова, що володіють культурними змістами, конотативними значеннями, проявами етнічної ментальності в мові. Лінгвокультурологічні одиниці - це ті, в яких культурні смисли реалізуються в культурних кодах (словах, символах, міфологемах, ідеологемах, стереотипах поведінки, знаках), а феномен етнічної ментальності проявляється в поведінці, в сукупності образів і уявлень, в ціннісних орієнтаціях етносу, виражених в словах (Khrolenko).

Репрезентуються лінгвокультуреми через: 1) народну поетичну творчість, яка $є$ невід’ємною частиною національної культури народу, важливим джерелом пізнання цивілізації й історії, відображенням суспільної свідомості нації; 2) пам'ятки історії, спеціальні історичні, філософські, соціологічні, літературознавчі, лінгвістичні, естетичні та інші дослідження; 3) вислови видатних діячів науки, мистецтва та літератури, в яких відображені найважливіші оцінки нації та національної особистості; 4) літературні твори, як вторинні модельовані системи, в яких знайшла художнє відображення національна особистість (типи та образи) та публіцистика; 5) видатні особистості, як модель національної особистості (наприклад Тарас Григорович Шевченко, Павло Глазовий, Леся Українка, Ярослав Мудрий - для української національної особистості; 
Чарльз Діккенс, Джек Лондон, Вільям Шекспір - для англійської національної свідомості; Генріх Гейне, Йоган Себастьян Бах, Йоган Вольфганг фон Гете - для німецької національної особистості); 6) думки й судження іноземців про певну націю та іiі культуру (Vorob'ev 56).

Концепт і лінгвокультурема є базовими для лінгвокультурології категоріями, які охопили різні аспекти наукового дискурсу, увійшли до спеціальних лінгвістичних словників. Водночас поряд із ними все більшої ваги набуває термін «міфологема». В останні десятиліття через потужний розвиток міфологічних інтерпретацій учені все частіше обговорюють проблему присутності міфологічного складника в мовній картині світу, визнають не тільки важливість «питання щодо ролі мови в переданні ритуалів, міфологічних схем, збереження слідів міфологічного мислення в конотаційній зоні окремих слів» (Sukalenko 4), а й про необхідність послугування спеціальним терміном для опису міфологічного компонента концептуальної картини світу.

Міфологема - термін для позначення стійких і повторюваних конструктів народної фантазії, що узагальнено відображують дійсність у вигляді чуттєво-конкретних персоніфікацій, істот і явищ, які мислились архаїчною свідомістю як цілком реальні. Цей термін загальновживана наукова лексика запозичила 3 психоаналізу Юнга. Міфологема також використовується для позначення запозичених міфологічних мотивів $\mathrm{i}$ перенесення їх у світ сучасної художньої культури. Інтерпретація терміна «міфологема» в сучасній лінгвістиці грунтована на концепції міфологій Р. Барта. За останньою провідним визначенням міфу є слово-міфологема як форма, наповнена соціальним змістом, зі своєю історичною межею й умовами вживання (Bart 38).

Міфологема - це образ, що породжується міфологічним мисленням, тобто є основою міфу. Водночас міф $\epsilon$ своєрідною формою пізнання дійсності, тобто поетичне уявлення про явища і предмети мовної картини світу. Міфи не потребують доведення чи спростування. Міф відрізняється від авторського міфу в тому, що останній додає власне бачення та інтерпретацію певних фактів, розширюючи межі людського пізнання.

Особливе значення поняття міфологеми має і з погляду дослідження лінгвістичної особистості автора художнього твору, оскільки теоретичною основою багатьох літературознавчих розвідок стали психоаналітичні дослідження міфу та міфотворчості. Сьогодні, зокрема, існує досить серйозний досвід вивчення формування й розвитку авторського міфу Лесі Українки. Сакральну суть творчості Лесі Українки дослідники вбачають у здатності ії слова творити істину в світі релятивізму й напівправди. Подібною до культурного героя міфу, найважливіша мета якого - творче перетворення світу, постає й сама авторка з ії високою місією слова.

Унікальним явищем у творчому доробку авторки є драма-феєрія «Лісова пісня». В ній міфопоетичне осмислення дійсності Лесею Українкою набуває нової якості - трансформується у власне авторську міфопоетику й одночасно ретранслює характерні особливості лінгвоперсони авторки. Зіставлення «Лісової пісні» 3 фольклором, 3 елементами збереженого в етнічній культурі українців поганського міфу виявляє моменти ідейної комунікації митця з уснопоетичною традицією, що формують «народність твору», а не програмують «зовнішній фольклоризм» (Ponomar'ov 213). I ця «народність», цей глибинний міфологізм «Лісової пісні» містять «принципові відмінності від структури та функціональності первісної міфології» (Polishchuk 213). Назагал простежується загальне, концептуальне трактування міфу як структури; якщо «традиційний міф утверджує вже укладену гармонію світу, то у драмі Лесі Українки йдеться про перспективу творення новітньої гармонії світу в людській любові» (Aheyeva 213).

Формування в уяві автора цілісної, наново створюваної міфопоетичної моделі світу детермінує творення гармонійного образу Мавки, що стає головним персонажем твору й основним втіленням творчих ідей. У «Лісовій пісні» полісемантичність і поліфункціональність цього персонажа української демонології показалася в усій повноті, демонструючи полігенезу утворення в надрах міфологічної свідомості. У цілому, в загальній концепції «Лісової пісні», у центральному ії образі Мавки дослідники простежують різні рівні творчої інтенції авторки - від одного з етапів «соціальної еволюції» авторки (Petrov 213) до створення образу «безсловесної» мови, що у Лесі стає прообразом ідеальної комунікації (Hundorova 213).

Міфологізація в «Лісовій пісні» простежувана на різних рівнях, зокрема на рівні відтворення топографіки природнього світу. Лексико-семантичне поле «місце дії» у драмі досить обмежене, однак за своїм смисловим навантаженням становить мікросвіт, що $є$ частиною Всесвіту. Текст ремарки до прологу має знакову природу: задається константа космогонічного ладу (провесна-передвибуховий творчий стан природи). «Предковічний ліс на Волині», вкритий містичною пеленою туману, який прориває вируюча сила життя (природи), втілена в образі «Того, що греблі рве». Зовнішній вигляд і поведінка цього персонажа передають ідею чоловічого начала, суперечливого за своєю природою: буяння життя, активність волевиявлення співіснують в цьому образі з силою руйнування. Образ «Того, що греблі рве», як і всі інші макро- та мікрообрази прологу, пов'язаний із символікою водної стихії, що створює міфопоетичну ситуацію, яка передує акту творіння, - народження кохання.

Образи рослин займають помітне місце в міфопоетичних уявленнях усіх стародавніх народів. Слов'яни, що жили переважно у лісах, одушевляли дерева, чагарники, квіти і злаки, тобто сприймали їх як живих істот, здатних відчувати, дихати, розмовляти. «3 багатьма рослинами пов’язані різноманітні заборони, повір'я i прикмети. Деякі рослини у традиційній свідомості сприймаються як місцеперебування нечистої сили або різних духів» (Bart 213). Створюючи культ рослинного світу, наші предки були переконані у необхідності шанобливого ставлення до природи: не можна бездумно рвати, пилити, рубити, оскверняти рослини, тим більше, що багато хто з них в народній свідомості наділялися особливою цілющою і магічною силою. 
Кожен образ рослинного світу у Лесі Українки ретельно продуманий. Мавка, сподіваючись на те, що поверне любов Лукаша, звиває собі вінок з гілок калини з червоними ягодами і йде в ньому назустріч коханому,

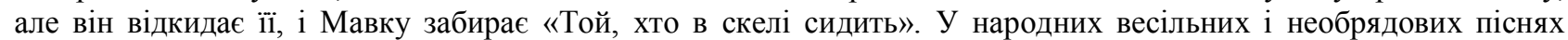
ламати калину означало любити когось, а сама калина символізувала дівоцтво, наречену. Але, як вірно пише Н. І. Костомаров: «У всіх слов'янських народів шлюб і поховання, любов і смерть мають між собою таємничу аналогію» (Kostomarov 119). В українській мові вираз «посадити червону калину» означає поховати когонебудь. Вирвавшись із царства смерті, Мавка носить на грудях маленький пучок калини, пояснюючи, що це ії кров. Важливе місце в драмі відводиться величезному столітньому дубу. Його шанують усі лісові мешканці, охороняє мудрий дядько Лев. Але після смерті старого дуб дозволяють зрубати і дерево продають матір $\mathrm{i}$ дружина Лукаша. Усі демонологічні істоти мстять їм, виганяють з лісу. У міфологічних уявленнях східних слов'ян дуб відіграє важливу роль, починаючи з язичницьких часів. У міфологічній системі наших предків він зв'язувався з культом бога грому і блискавки Перуна. У східнослов'янській народній культурі існувало уявлення про взаємозв'язок дуба і людини. У драмі Л. Українки величаве дерево символізує міць і моральну чистоту усього лісового царства. Майстерно і вмотивовано ввівши у канву свого твору міфологізовані образи рослин, Леся Українка створила справжній поетичний шедевр про гармонію світу природи зі світом людей, про всеперемагаючу силу любові та духовної повноцінності людини.

Стихія води у творі містить закодовану символіку первинного хаосу, що очікує оживлення святим духом. Водночас, ця рухлива магма набуває ознак істоти, що «пожирає» творіння. Завдяки надзвичайній силі творіння, вода в архаїчній свідомості репрезентує жіноче начало, семантику народження. У дохристиянських віруваннях архетипи води передають дихотомію життя-смерті. Асоціативна низка концепту «вода» у творі репрезентована такими лексемами: море, хвиля; дощик; холодні роси; живущі сльози; кров; драговина, болото.

У драмі-феєрії Лесі Українки було визначено основні міфологеми, що свідчать про міфологізацію художнього тексту. Це Той, що греблі рве, Русалка, Водяник, Потерчата, Метелиця Гірська та Той, що в скалі сидить. Кожна міфічна істота характеризується чітко визначеними стереотипними ознаками чи властивостями, що свідчить про те, що язичницька віра українців ще й досі залишається у підсвідомості. Так, мавка, за словниковим визначенням, це казкова лісова істота в образі гарної голої дівчини з довгим розпущеним волоссям; лісова німфа (SUM 4: 587). В українській свідомості ця міфічна істота може асоціюватися і з водяною німфою, тобто русалкою. У художньому тексті авторка зберігає всі стереотипи щодо опису цієї міфічної істоти: «Мавка, в ясно-зеленій одежі, з розпущеними чорними з зеленим полиском косами, розправляє руки і проводить долонею по очах». Про язичницьке вірування українців в драмі-феєрії також свідчать і такі описові (евфемістичні) назви Той, що греблі рве і Той, що в скалі сидить. Як вважали українці, того, кого остерігалися, не називали за іменем.

Втілені в «Лісовій пісні» міфологеми запозичені зі скарбниці давніх українських вірувань і міфів. Ці міфологеми грунтовані на системі перетворень. Мавка перетворюється на вербу, а потім, згорівши, з'являється білою прозорою постаттю. Лукаш стає вовкулакою, а потім - знову людиною. Перелесник блискавкою злітає на дерево, щоб врятувати душу Мавки, і все спалахує у вогні. Ремарки фіксують зміни в природі: рання весна розцвітає, згодом переходить у пізнє літо, тоді - в осінь, а далі - у зиму.

У «Лісовій пісні» втілилося народне сприйняття навколишнього світу, давнє міфологічне мислення українців. Гостро постає проблема відносин людини і природи, які дуже часто $є$ негармонійними. Людина звикла ставитися до природи, як до засобу, використовуючи природні дари егоїстично і нерозумно. Мавка $\epsilon$ втіленням не тільки прекрасної і беззахисної природи, але й краси душі людини, яка не може бути знищена у дрібних повсякденних турботах. Вона вічно відроджується.

Висновки та перспективи подальших досліджень. Підсумовуючи, можна припустити, що міфологеми «Лісової пісні» визрівали у площині фольклору та міфопоетики, але сам міф надав творові лише прийоми, канву та фабульний бік, оскільки її сюжет повністю належить авторові. Таким чином, міфопоетика Лесі Українки $є$ для письменниці своєрідним синтезом міфології та елементів власне авторського світобачення. Тому міфологічні елементи своєрідно вплітаються у композиційний каркас твору. Образи письменниці, хоч i взяті з міфології і фольклору, проте не є носіями всіх характеристик останніх. Міфологеми стародавнього культурного простору набувають індивідуально-авторського символічного значення. Художній потенціал використаних засобів підпорядкований художній меті - осмислити витоки світоглядних настанов попередніх поколінь, наблизити їх до національної духовної культури сучасності. Міфологеми, переплетені з образами української ментальності, формують оригінальний мовний простір драматургічної спадщини Лесі Українки.

Обрана тема статті може бути розкрита в ширших масштабах, наприклад на матеріалі лірики Лесі Українки у повному обсязі. До того ж драматичні поеми Лесі Українки заслуговують окремого дослідження у царині міфологізму.

\section{References}

Aheyeva V. Neoromantychne dvosvittya «Lisovoyi pisni» (Neo-Romantic of "Forest song's" two-world). "Yim promovlyaty dusha moya bude". "Lisova pisnya" Lesi Ukrayinky ta yiyi interpretatsiyi ("My soul will speak to them". "Forest song" by Lesya Ukrainka and her interpretations) Kyiv: Fakt, 2002. Print.

Bart, Rolan. Myfolohyy (Mythology). Moskva.: Yzd-vo ym. Sabashnykovykh, 2000. Print. 
Fedorov, Anatoliy. Zarubezhnaya lyteratura XIX - XX vekov. Estetyka y khudozhestvennoe tvorchestvo (Foreign literature of the XIX-XX centuries. Aesthetics and artistic creativity). Moskva.: MU, 1989. Print.

Hundorova T. Femina Melancholica. Stat' i kul'tura v henderniy utopiyi Ol'hy Kobylyans'koyi (Femina Melancholica. Gender and culture in the gender utopia of Olha Kobylianska). Kyiv: Krytyka, 2002. Print.

Karasyk, Vladymyr, and Slyshkin, Henadiy. Lynhvokul'turnyy kontsept kak edynytsa yssledovanyya (Linguocultural concept as a unit of study). Metodolohycheskye problemy kohnytyvnoy lynhvystyky (Methodological problems of cognitive linguistics). Ed. by Yosyf Sternyn. Voronezh: VHU, 2001. Print.

Khrolenko, Aleksandr. Osnovy lynhvokul'turolohyy (Basics of linguoculturology). Moskva.: Nauka, 2006. Print.

Kostomarov M. Slavyanskaya myfolohyya (Slavic mythology). Kyiv: Lybid', 1994. Print.

Kyryllova, Nyna, and Afanas'eva, Alla. Praktycheskoe posobye po lynhvokul'turolohyy: frantsuzskyy yazyk (Practical guide to linguistics: French). Sankt-Peterburh: SPbHU, 2008. Print.

Meletynskyy, Yelyezar. Poetyka myfa (Poetics of myth). Moskva.: Nauka, 1995. Print.

Petrov V. "Lisova pisnya" ("Forest song"). "Yim promovlyaty dusha moya bude". "Lisova pisnya" Lesi Ukrayinky ta yiyi interpretatsiyi ("My soul will speak to them". "Forest song" by Lesya Ukrainka and her interpretations). Kyiv: Fakt, 2002. Print.

Polishchuk Ya. "Estetyka mifu i mifolohichnyy horyzont rann'oho ukrayins'koho modernizmu” ("Aesthetics of myth and mythological horizon of early Ukrainian modernism"). Diss. Kyiv, 2000. Abstract. Print.

Ponomar'ov P. "Fol'klorni dzherela «Lisovoyi pisni» Lesi Ukrayinky" “(Folklore sources of "Forest song” by Lesya Ukrainka). Materialy do vyvchennya istoriyi ukrayins'koyi literatury. Kyiv: Naukova dumka, 1961.

Slovnyk ukrayins'koyi movy (Dictionary of the Ukrainian language). Akademichnyy tlumachnyy slovnyk (Academic dictionary). Kyiv: Naukova dumka, 1973. Web. 20 Zhov. 2018.

Sukalenko, Nonna. "O pryrode symvola" (“About the nature of the symbol”). Visnyk Kharkivs'koho universytetu (Bulletin of Kharkiv University). Filolohiya 448 (1999). 3-5. Print.

Telyya, Veronyka. Russkaya frazeolohyya: semantycheskyy, prahmatycheskyy y lynhvokul'turolohycheskyy aspekty (Russian phraseology: semantic, pragmatic and linguocultural aspects). Moskva: Yazyky russkoy kul'tury, 1996. Print.

Vorob'ev, Vladymyr. Lynhvokul'turolohyya (Cultural linguistics). Moskva: RUDN, 2006. Print.

Zahnitko, Anatoliy. Teoriya linhvopersonolohiyi (Theory of linguistic personology). Vinnytsya: Nilan-Ltd, 2017. Print.

Zahnitko, Anatoliy, and Bohdanova, Iryna. Linhvokul'turolohiya (Cultural linguistics). Ed. by Anatoliy Zahnitko. Vinnytsya: DonNU, 2017. Print.

Zahnitko, Anatoliy. "Klasyfikatsiyni typolohiyi kontseptiv" ("Classification of the typology of concepts"). Linhvistychni studiyi (Linguistic studies) 21 (2010). 12-21. Print.

Надійшла до редакції 10 листопада 2018 року.

\section{LESIA UKRAINKA'S MIFOPOETIC WORLD: LINGUOPERSONOLOGICAL ASPECT}

Olena Polishchuk

Faculty of Philology, Department of General and Applied Linguistics and Slavic Philology, Vasyl' Stus Donetsk National University, Vinnytsia, Ukraine

$\underline{\text { Abstract }}$

Background: The research of a writer concept sphere is an actual problem of modern linguistics because of developing of the anthropological direction, examining the individual authors linguistic picture, which is encoded in lexemes.

Purpose: The purpose of the analysis is to determine the features of Lesya Ukrainka's linguistic personality through the poetics of myth.

Results: Myth denotes a steady and repetitive constructs of people's imagination, which are reflecting the reality in the form of sensory-specific personifications, of beings and phenomena, which archaic consciousness comprehends as realistic. The plant symbols, the images of heroes, the topography of the natural world, the descriptions of the elements embody the myth in the "Forest song" by Lesya Ukrainka.

Discussion: Lesya Ukrainka' mythopoetics is a kind of synthesis of mythology and elements of own author's worldview. Therefore, mythological elements are woven into the composition framework. Myths of the ancient cultural space become the author's individual symbolic meaning.

Keywords: concept, mythologeme, mythopoetics, linguistic personology, linguistic person, idiostyle.

Vitae

Olena Polishchuk is a student of the Vasyl' Stus Donetsk National University. She is studying at the Faculty of Philology at the Department of General and Applied Linguistics and Slavic Philology.

Correspondence: onishko.o@donnu.edu.ua 